Scientia Agricola

http://dx.doi.org/10.1590/0103-9016-2015-0041

Note

\title{
Physico-chemical properties and amino acid profiles of sap from Tunisian date palm
}

\author{
Ines Makhlouf-Gafsi ${ }^{1}$, Abir Mokni-Ghribi ${ }^{1}$, Brahim Bchir², Hamadi Attia ${ }^{1}$, Christophe Blecker ${ }^{2}$, Souhail Besbes ${ }^{1 *}$
}

'University of Sfax/National School of Engineers of Sfax Dept. of Biology -Nutritional Analysis Lab., Rod. Soukra Drive - 3038 - Sfax - Tunisia.

2University of Liège - Gembloux Agro-Biotech -Lab. of Food Technology, Passage des Déportés, 2- 5030 - Gembloux Belgium.

*Corresponding author <besbes.s@voila.fr>

Edited by: Luís Guilherme de Lima Ferreira Guido

Received February 06, 2015

Accepted May 19, 2015
ABSTRACT: Date palm sap (Phoenix dactylifera L.), also known as "legmi", is a fresh juice extracted from date palm trees. The present study aimed to elucidate the effects of collection time (at the beginning of the tapping period and after seven days of collection) on the amino acid profile and physico-chemical properties of date palm sap from both male and female trees. Dry matter, protein, amino acid, and sugar profiles were determined using the Kjeldahl method, High-Performance Liquid Chromatography (HPLC), and High-Performance Anion-Exchange Chromatography with Pulsed Amperometric Detection (HPAEC-PAD), respectively. Date palm sap from both male and female trees contained high levels of carbohydrates. HPLC analysis showed that this fraction was dominated by sucrose in the sap sample from female trees compared to that from male trees. Male date palm sap was noted to exhibit lower dry matter content than female date palm sap but higher protein, total polyphenol, ash, and amino acid contents. While the major essential amino acids in the sap from male trees consisted of valine and threonine, they were represented by lysine and phenylalanine in sap samples from female trees. Further, Sodium Dodecyl Sulfate Polyacrylamide Gel Electrophoresis (SDS-PAGE) analysis showed the presence of a proteinic band of $30 \mathrm{kDa}$ only for the sap from male trees. Taken together, the sap from both male and female date palm trees had a number of properties that are highly valued by the functional food industry.

Keywords: male date palm, female date palm, time of sap collection, sex discrimination

\section{Introduction}

Date palm (Phoenix dactylifera L.) is a woody, perennial and dioecious plant species, with separate male and female trees, belonging to the Arecaceae family. It is widely cultivated in various arid and semi-arid regions throughout the world, including North African, Middle Eastern, and Arabian Gulf countries, where it plays significant socio-cultural, economic, and ecological roles. In Tunisia, for instance, date palm oases cover about 46,000 ha and supply around 100 million US dollars to total annual exports in value (FAO, 2008). This sector contributes approximately $4 \%$ to the total value of agricultural production and $13 \%$ of the total value of agricultural exports from Tunisia. In addition to date fruits, palm trees offer several other derivatives (such as leaves, trunks, and seeds), which are used for various traditional and industrial activities such as roofing, fencing, basket making, and animal feeding (Besbes et al., 2009).

Date palm sap, known in Tunisia as "legmi", is one of the popular derivatives of date palm trees. It is a sugary drink traditionally collected by various tapping techniques. The extraction of date palm sap is a delicate process involving the removal of all the leaves except some of the outer circle to give support to the tapper and the careful incision at the top of the trunk into a cone shape from which sap is collected and guided into a container suspended on the side of the tree. The collection period generally lasts from three to four months (March-June) during which a palm tree can of- fer a total sap yield of up to $500 \mathrm{~L}$ (Barreveld, 1993). The quantity and quality of the sap depend on several factors, including the tree's age, variety, area of origin and especially the moderate tapping procedure, which does not lead to the sacrifice of the palm tree after the operation.

Despite a long history of human production and consumption, little data is currently available on the compositional profile and nutritional values of this natural resource. Traditionally, "legmi" is consumed as a refreshing drink or as an alcoholic beverage after natural fermentation. In fact the use of the sap from Phoenix dactylifera L. date palm, as well as from several other species, such as Phoenix sylvestris, Cocos nucifera, Raphia hookeri and Elaeis guineensis, is restricted (Atputharajah et al., 1986; Dalibard, 1999; Umerie, 2000). The value addition of this natural by-product is limited to the production of syrups (Ben Thabet et al., 2010a).

Despite the large flow of data on the promising nutritional and functional properties of sap syrups from various palm varieties, to our knowledge, no study has so far reported on the amino acid composition of the sap from Phoenix dactylifera L. palm trees. Data currently available on the effects of palm sex and collection time on the quality of sap from this variety are also very limited, if not absent. Accordingly, the present study aimed to investigate the effects of collection time (at the beginning of the collection period and after 7 days) on the physico-chemical composition and amino acid profile of Deglet Nour date palm sap from both male and female trees. 


\section{Materials and methods}

\section{Collection and preservation of sap samples}

Date palm sap was collected from a palm grove in Tunisia from three males and three females from the same date palm (Phoenix dactylifera L.) cultivar, named Deglet Nour. This cultivar was selected because it is the most abundant in Tunisia (more than $70 \%$ of cropped Tunisian palm) (Ben Thabet et al., 2009). In addition, these palms are grown from seeds. Date palms were subjected to the same sunlight, mineral nutrition, and watering conditions. Samples were collected at two different times during the collection period: the first day and seven days after the beginning of sap collection) using the traditional tapping method (Barreveld, 1993). Sodium azide (g L ${ }^{-1}$ ) was added to all sap samples immediately after collection to prevent microbial growth. The samples were immediately stored in an ice box $\left(4^{\circ} \mathrm{C}\right)$ and transported (60 min) to the laboratory for analysis. All analytical determinations were performed in triplicate, and values were expressed as the mean \pm standard deviation $(\bar{\chi} \pm S D)$.

\section{Physico-chemical analyses}

Dry matter content was determined by oven drying at $103{ }^{\circ} \mathrm{C}$ until constant weight. Protein content was measured by the Kjeldahl method using a protein conversion factor of 6.25. Ash content was estimated by ashing $5 \mathrm{~g}$ of sap in a Muffle furnace (Nabertherm, Germany) at $550{ }^{\circ} \mathrm{C}$ for $6 \mathrm{~h}$. Total phenols were determined colorimetrically with the Folin-Cicalteau reagent at $760 \mathrm{~nm}$ as described by Gutfinger (1981). Sugar profile was determined by HPLC. The Brix degree was measured with a refractometer(Germany) at $20^{\circ} \mathrm{C}$. The color of the palm sap samples was determined by a colorimeter (UK). The CIELAB coordinates $\left(\mathrm{L}^{*}, \mathrm{a}^{*}, \mathrm{~b}^{*}\right)$ were also measured. The $L^{*}$ value varied from 0 (black) to +100 (white), the $a^{*}$ value varied from -120 (green) to +120 (red), and the $b^{*}$ value varied from -120 (blue) to +120 (yellow).

\section{Sugar profile}

Individual sugars were extracted from the sap of male and female trees with $10 \mathrm{~mL}$ of ethanol solution $(80$ $\%)$. The extracts were centrifuged $(1,344 \mathrm{x} \mathrm{g}, 30 \mathrm{~min})$ and filtered via nylon filter $(0.45 \mu \mathrm{M})$. Sucrose, glucose, and fructose were analyzed with high performance anion exchange chromatography coupled with pulse amperometric detection on a chromatographic system operating at

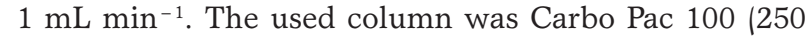
$\times 4 \mathrm{~mm})$, CA. The buffers used for elution were sodium hydroxide $(100 \mathrm{mM})$ and sodium acetate $(500 \mathrm{mM})$ at $30{ }^{\circ} \mathrm{C}$. The pressure and temperature were $6894.75 \mathrm{kPa}$ and $80{ }^{\circ} \mathrm{C}$, respectively. External standards of fructose, glucose and sucrose were used for quantification (Bchir et al., 2010).

\section{Amino acid profiles}

Amino acids were determined by high performance liquid chromatography (HPLC) according to the OJEC standard method (European Union, 1998). Sap samples $(10 \mathrm{~mL})$ from male and female palms were hydrolysed with $\mathrm{HCl}(6 \mathrm{M})$ in an ampoule containing $10 \mathrm{mg}$ phenol (for protection of tyrosine) at $110{ }^{\circ} \mathrm{C}$ for $24 \mathrm{~h}$. After acid hydrolysis, $30 \mathrm{~mL}$ of citrate buffer $(\mathrm{pH} 2.2)$ were added, and the $\mathrm{pH}$ was adjusted to between 0.5 and 1 with a $7.5 \mathrm{M} \mathrm{NaOH}$ and $\mathrm{pH} 2.2$ with a $1 \mathrm{M} \mathrm{NaOH}$. The sample obtained was diluted to $100 \mathrm{~mL}$ with citrate buffer after adding $1 \mathrm{~mL}$ of a norleucine solution $50 \mu \mathrm{M}$ (as an internal standard). The sample was filtered through a 0.2 $\mu \mathrm{M}$ nylon filter before being analyzed by HPLC. Sulphurcontaining amino acids, cysteine and methionine were determined after pre-hydrolysis oxidation with performic acids. The contents of the recovered amino acids were expressed in \% (protein basis). The HPLC system (Berlin, Germany) was equipped with a UV-vis detector with two wavelengths, $440 \mathrm{~nm}$ and $570 \mathrm{~nm}$, respectively for the proline and the other amino acids, and a cation exchange Waters C18 column (4.6 mm $\times 200 \mathrm{~mm}$ ) (Dublin, Ireland). Resolution of amino acid derivatives was achieved using a four buffer gradient system. The buffers used were: (A) $0.2 \mathrm{M} \mathrm{Na}$ citrate (pH 3.2), (B) $0.2 \mathrm{M} \mathrm{Na}$ citrate ( $\mathrm{pH} 4.25)$, (C) $1.2 \mathrm{M} \mathrm{Na}$ citrate (pH 6.45) and (D) $0.4 \mathrm{M} \mathrm{NaOH}$.

\section{Protein profile}

Extraction procedure - Sap samples from male and female palms were precipitated with $80 \%$ saturated sulfate ammonium in accordance with Dawsan et al.,(1969).The samples were then centrifuged at $10,000 \mathrm{x}$ g and $4{ }^{\circ} \mathrm{C}$ for $20 \mathrm{~min}$. The precipitates were washed twice with distilled water, dialyzed against distilled water for $24 \mathrm{~h}$ at $4{ }^{\circ} \mathrm{C}$, and lyophilized.

Sodium dodecyl sulphate polyacrilamide gel - The molecular weight profile of protein from the sap extract of male and female palms was established using polyacrylamide gel (12\%) according to Laemlli's method (1970). Fifty milligrams of the extracts were added to $0.75 \mathrm{~mL}$ of phosphate-buffered saline (PBS) buffer. The preparation was then centrifuged at $10,000 \mathrm{x} g$ for $20 \mathrm{~min}$, and the supernatant was employed for electrophoresis. The protein bands were visualised with Coomassie brilliant blue. The molecular weights of the proteins from each sample were determined using the broad spectrum molecular weight standard.

Statistical analyses - Data were analysed by the Statistical Package for Social Sciences software (SPSS for windows version 16.0). Duncan's test was performed at the level of $p \leq 0.05$ to determine significant differences between the values of the means (Kilincceker, 2009).

\section{Results and discussion}

\section{Physico-chemical properties}

All the male and female date palm sap samples had $\mathrm{pH}$ values near neutral (Table 1). This is, in fact, in 
Table 1- Physico-chemical characteristics of male and female date palm sap.

\begin{tabular}{|c|c|c|c|c|}
\hline \multirow{2}{*}{ Parameter } & \multicolumn{2}{|c|}{ Male date sap } & \multicolumn{2}{|c|}{ Female date sap } \\
\hline & Time $=0$ days & Time $=7$ days & Time $=0$ days & Time $=7$ days \\
\hline $\mathrm{pH}$ & $6.86 \pm 0.05^{a}$ & $6.87 \pm 0^{a}$ & $6.88 \pm 0^{a}$ & $6.88 \pm 0.05^{a}$ \\
\hline Brix degree & $10.70 \pm 0.20^{c}$ & $8.50 \pm 0.20^{d}$ & $16.7 \pm 0.20^{\mathrm{a}}$ & $14.70 \pm 0.20^{b}$ \\
\hline Dry matter (\%) & $9.69 \pm 0.02^{c}$ & $8.05 \pm 0.06^{d}$ & $15.63 \pm 0.01^{a}$ & $14.05 \pm 0.08^{b}$ \\
\hline Protein $^{*}$ & $5.28 \pm 0^{\mathrm{b}}$ & $7.59 \pm 0.005^{\mathrm{a}}$ & $3.38 \pm 0.03^{c}$ & $3.45 \pm 0.02^{c}$ \\
\hline Ash $^{*}$ & $6.24 \pm 0.23^{b}$ & $7.00 \pm 0.15^{\mathrm{a}}$ & $2.28 \pm 0.01^{d}$ & $2.89 \pm 0.14^{c}$ \\
\hline Total Polyphenols ** & $2.04 \pm 0.11^{\mathrm{a}}$ & $1.97 \pm 0.14^{b}$ & $1.64 \pm 0.11^{c}$ & $1.43 \pm 0.05^{d}$ \\
\hline \multicolumn{5}{|l|}{ Colour parameters } \\
\hline$L^{*}$ & $66.30 \pm 0.01^{\mathrm{b}}$ & $66.15 \pm 0.13^{c}$ & $54.99 \pm 0.13^{d}$ & $66.35 \pm 0.02^{\mathrm{a}}$ \\
\hline$a^{*}$ & $1.62 \pm 0.01^{b}$ & $1.29 \pm 0.01^{d}$ & $2.45 \pm 0^{\mathrm{a}}$ & $1.45 \pm 0.01^{c}$ \\
\hline$b^{*}$ & $14.30 \pm 0.01^{c}$ & $17.54 \pm 0.01^{\mathrm{a}}$ & $16.89 \pm 0.07^{b}$ & $13.80 \pm 0.01^{d}$ \\
\hline
\end{tabular}

${ }^{*}$ In $\%$ dry matter basis; ${ }^{*} \ln \mu g \mathrm{~mL}^{-1}$; Means in the same line, with different small letters are different $(p<0.05)$.

agreement with the results previously reported for the sap from the Deglet Nour date palm variety (Ben Thabet et al., 2009), wild date palm (Naidu and Misra, 1998), and coconut (Atputharajah et al.,1986). Differences were, however, recorded for the Brix values of the male and female date palm sap samples $(p<0.05)$. This result is consistent with the findings previously observed for Borassus flabellifer grown in Cambodia (Khieu and Preston, 1995).

The results further indicated that the Brix value was affected by the time of the tapping. Brix decreased $(p<0.05)$ after one week of tapping. Moreover, the male date palm sap contained lower dry matter content than the female date palm sap (10\% vs.16\% respectively). After one week of tapping, the dry matter content decreased $(p<0.05)$ in both male and female date palm saps. This could presumably be attributed to the stress imposed on the plants by the daily tapping procedure. In fact, several nutrient elements were removed from the palm trunk (Obahiagbon and Osagie, 2007).

Furthermore, the protein content in male date palm sap was higher than the one from female trees 15 $\%$ vs. $3 \%$ dry matter basis, respectively). After one week of tapping, the protein content remained constant in female sap but rose in the male sap ( $p<0.05)$. The male date palm sap exhibited higher total phenolic content than the female $(2.04 \mathrm{vs} .1 .648 \mu \mathrm{g}$ gallic acid equivalent $\mathrm{mL}^{-1}$ of total polyphenol, respectively). These values are relatively lower than those previously reported for Deglet Nour palm sap (Ben Thabet et al., 2009) but comparable to those of Regnault-Roger et al. (1987).

The ash content recorded for male date palm sap was higher than the one observed for female sap $16 \%$ vs. 2 $\%$ dry matter, respectively). After one week of tapping, an increase in the ash content for both male and female saps was recorded $(p<0.05)$. This could presumably be due to the effects of the daily tapping procedure, which induced a decline in the nutritive level of constituent elements. To overcome this stress, the plant employs a supplementary system of absorption of mineral elements. The Cielab $\left(\mathrm{L}^{*}, \mathrm{a}^{*}, \mathrm{~b}^{*}\right)$ values of both male and female date palm sap proved the clarity of this natural juice. Compared to those previously reported for Deglet Nour sap, both male and female saps were darker (Lower $\mathrm{L}^{*}$ ) and a lighter red color (Lower $\mathrm{a}^{*}$ ) (Ben Thabet et al., 2009). Plant sex may affect the quality of the sap (Phoenix dactylifera L.). This result is in agreement with previous reports on sap from the Borassus flabellifer palm in Borma, where up to six qualities of sap were differentiated based on the tapping stage and plant sex (Dalibard, 1999).

\section{Sugar profile}

Sugar was the major constituent in both male and female date palm sap, which is consistent with the findings reported for the sap from Phoenix sylvestris and Borassus flabellifer (Rao et al., 2009). Compared to male date palm sap, female palm sap exhibited higher levels of sugar content. It was observed that these rates increased after one week of tapping.

While the sugar fraction in the female date palm sap was dominated by sucrose (63\% dry matter basis), no difference $(p>0.05)$ was detected between the sucrose and glucose contents $(36 \%$ and $33 \%$ respectively) for the male palm sap (Table 2). After one week of tapping, the sucrose rate in the male and female saps decreased, whereas the glucose and fructose contents increased. This can be attributed to the involvement of invertase activity, which catalyses the hydrolysis of sucrose into an equimolar mixture of glucose and fructose. Similar rates of increase should, therefore, be recorded for both glucose and fructose contents. However, the increase in fructose content was lower than the one recorded for glucose. This result could presumably be ascribed to glucose -6-phosphate isomerase activity, a non rate-limiting enzyme in glycolysis, which catalyses the reversible isomerisation of glucose-6-phosphate to fructose-6-phosphate (Haller et al., 2011). Such invertase and glucose-6-phosphate isomerase activities could be attributed to the proteins involved in glycolysis and related to Saccharomyces cerevisiae which belongs to the natural microflora of date palm sap (Ben Thabet et al., 2010b).

\section{Amino acid profile}

Female date palm sap exhibited higher amino acid content than the male palm sap (Table 3). After one week 
Table 2 - Sugar composition of male and female date palm sap.

\begin{tabular}{|c|c|c|c|c|}
\hline \multirow{2}{*}{ Parameter } & \multicolumn{2}{|c|}{ Male date sap } & \multicolumn{2}{|c|}{ Female date sap } \\
\hline & Time $=1$ days & Time $=7$ days & Time $=1$ days & Time $=7$ days \\
\hline Glucose * & $33.45 \pm 0.81^{\mathrm{Ab}}$ & $48.56 \pm 2.93^{\text {Аа }}$ & $16.88 \pm 0.28^{\mathrm{Bd}}$ & $25.83 \pm 1.93^{B C}$ \\
\hline Fructose ${ }^{*}$ & $1.42 \pm 0.21^{\mathrm{Bc}}$ & $3.55 \pm 0.13^{\mathrm{ca}}$ & $1.14 \pm 0.09 c c$ & $2.61 \pm 0.14^{\mathrm{cb}}$ \\
\hline Sucrose* & $35.54 \pm 1.45^{\mathrm{Ac}}$ & $19.96 \pm 0.86^{B d}$ & $63.38 \pm 0.92^{\mathrm{Aa}}$ & $57.14 \pm 0.06^{\mathrm{Ab}}$ \\
\hline Total $^{*}$ & $70.401 \pm 2.3^{d}$ & $72.07 \pm 4.01^{c}$ & $81.40 \pm 1.32^{\mathrm{b}}$ & $85.58 \pm 2.13^{a}$ \\
\hline
\end{tabular}

${ }^{*}$ In $\%$ dry matter basis. Means in the same line, with different small letters are different $(p<0.05)$. Means in the same column, with different capital letters are different $(p<0.05)$.

Table 3 - Amino acid composition of male and female date palm sap.

\begin{tabular}{|c|c|c|c|c|c|}
\hline \multirow{2}{*}{ Amino acid $^{*}$} & \multirow{2}{*}{ Retention Time (min) } & \multicolumn{2}{|c|}{ Male date sap } & \multicolumn{2}{|c|}{ Female date sap } \\
\hline & & Time $=1$ days & Time $=7$ days & Time $=1$ days & Time $=7$ days \\
\hline Asp & 12.6 & $12.76 \pm 0.19^{\mathrm{Aa}}$ & $11.94 \pm 0.01^{\mathrm{Bb}}$ & $4.97 \pm 0.12^{\mathrm{Cd}}$ & $5.82 \pm 0.06^{c c}$ \\
\hline Thr & 14.7 & $1.18 \pm 0.02^{\mathrm{Fb}}$ & $0.97 \pm 0^{\mathrm{Gc}}$ & $1.27 \pm 0.03^{\mathrm{Ja}}$ & $1.27 \pm 0.03^{\text {la }}$ \\
\hline Ser & 16.0 & $1.38 \pm 0.19^{\mathrm{Ec}}$ & $1 \pm 0^{\mathrm{Gd}}$ & $1.86 \pm 0.03^{\mathrm{Fb}}$ & $2.05 \pm 0.03^{\mathrm{Ea}}$ \\
\hline Glu & 20.4 & $6.91 \pm 0.02^{c d}$ & $13.17 \pm 0^{A C}$ & $14.52 \pm 0.03^{\mathrm{Ab}}$ & $15.59 \pm 0.23^{\mathrm{Aa}}$ \\
\hline Gly & 28.4 & $1.38 \pm 0^{\mathrm{Ed}}$ & $1.56 \pm 0.01^{\mathrm{Eb}}$ & $1.45 \pm 0^{\text {lc }}$ & $1.79 \pm 0.03^{\mathrm{Fa}}$ \\
\hline Ala & 30.2 & $6.79 \pm 0.02^{\mathrm{Ba}}$ & $4.19 \pm 0.01^{\mathrm{cb}}$ & $1.48 \pm 0.03^{\mathrm{Hd}}$ & $1.51 \pm 0.03^{\mathrm{Hc}}$ \\
\hline Cys-cys & 31.3 & ND & $0.67 \pm 0.01^{\mathrm{H}}$ & ND & ND \\
\hline Val & 32.2 & $1.42 \pm 0.02^{\mathrm{Dd}}$ & $1.46 \pm 0.01^{\mathrm{Fc}}$ & $1.71 \pm 0.03^{\mathrm{Gb}}$ & $1.74 \pm 0.03^{\mathrm{Ga}}$ \\
\hline \|le & 40.1 & ND & ND & $4.73 \pm 0.03^{D}$ & ND \\
\hline Phe & 46.6 & ND & ND & $0.95 \pm 0.03^{\llcorner\mathrm{b}}$ & $1.13 \pm 0.03^{\mathrm{Ja}}$ \\
\hline His & 60.6 & ND & $0.69 \pm 0.01^{\mathrm{Hc}}$ & $1.18 \pm 0^{\text {Ка }}$ & $1.04 \pm 0^{\mathrm{Kb}}$ \\
\hline Lys & 61.6 & $0.47 \pm 0.02^{\mathrm{Gd}}$ & $1.01 \pm 0^{\mathrm{Gc}}$ & $3.22 \pm 0.08^{\mathrm{Ea}}$ & $2.49 \pm 0.03^{\mathrm{Db}}$ \\
\hline $\operatorname{Arg}$ & 73.9 & $0.47 \pm 0^{\mathrm{Gd}}$ & $3.74 \pm 0.01^{\mathrm{Dc}}$ & $8.96 \pm 0.03^{\mathrm{Ba}}$ & $6.89 \pm 0.16^{\mathrm{Bb}}$ \\
\hline Total & & $32.76 \pm 0.34^{d}$ & $39.08 \pm 0.43^{c}$ & $42.01 \pm 0.4^{a}$ & $41.32 \pm 0.67^{b}$ \\
\hline
\end{tabular}

${ }^{*}$ In \% protein content basis. ND: not detected. Means in the same line, with different small letters are different $(p<0.05)$. Means in the same column, with different capital letters are different $(p<0.05)$.

of tapping, this content increased $(p<0.05)$ in the male sap. Similar to most plants, the free amino acid pool of both male and female saps (Table 3) was dominated by glutamine, asparagine (Fischer et al., 1998), and arginine (Salaün and Charpentier, 2001). In fact, the synthesis of glutamine is the major pathway for the assimilation of ammonium into organic matter, and asparagine represents the major receiver of the nitrogen of glutamine and a mobile reservoir for transport to growth sites (Joy, 1988). Arginine, on the other hand, is a precursor of the biosynthesis of polyamines and nitric oxide, which are involved in almost all physiological and biochemical processes as well as in plant growth and adaptation to stress (Yang and Gao, 2007). The essential amino acids present in male date palm sap were valine and threonine, whereas those present in the female were lysine and phenylalanine.

Unlike female date palm sap, male sap does not contain phenylalanine. This last amino acid is a precursor of the biosynthesis of salicylic acid, one of the major phytohormones involved in sex determination (Golenberg and West, 2013). In fact, different phytohormones are implicated in this process, and the same phytohormone can have varying effects depending on the plant. For example, while Gibberellic acid has a masculinizing effect in Solanum carolinense, Asparagus officinalis, Cori- andrium sativum, Cannabissativus, and Spinacia oleracea, it has a feminizing effect in Luffa acutangula, Hyoscyamus niger and Zea mays (Golenberg and West, 2013). Accordingly, the results presented in this work suggest that salicylic acid is feminizing in date palm.

\section{Electrophoretic profile of Date palm sap}

The SDS-PAGE protein profiles of male and female saps were similar and revealed three main bands (Figure 1). The predominant protein bands had a molecular weight of about $60 \mathrm{kDa}, 50 \mathrm{kDa}$ and $40 \mathrm{kDa}$, corresponding to the molecular weight ranges of fruits from 18 of the most commonly eaten cultivars previously described by Kwaasi et al. (2008). However, a proteinic band of around $30 \mathrm{kDa}$ was identified for the male date palm sap. This band was peculiarly present in the SDS-PAGE profile of Allig and Deglet Nour extracts from defatted date seeds (Bouaziz et al., 2008) and several date fruits. In fact, it was also identified in Californian cultivars and several Easten dates described by Ahmad et al. (1995) (Buraringa, Barneh, Fardh, Hilali and Zabad) and Kwaasi et al. (2008) (Labana, Barhi, Mabroom, Roshidia, Halaw, Qattar and Nabtat Jannah).

The previously described results and unique proteomic study on date palm sap (Ben Thabet et al., 2010b) confirm that this protein $(30 \mathrm{kDa})$ was a plant protein 


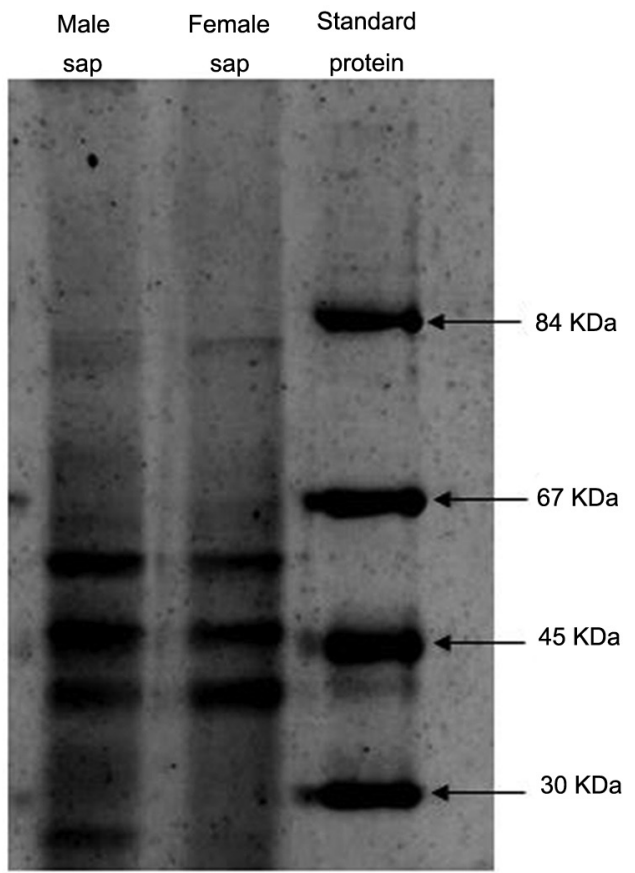

Figure 1 - Electrophoretic profiles of soluble proteins from male and female date palm sap on a $10 \%$ polyacrylamide gel by sodium dodecyl sulphate (SDS-PAGE) compared with the profile of a standard protein.

which could be involved in various biological functions, including redox regulation, stress responses, defence reactions, signal and transport pathways, and carbohydrate metabolism. All proteins identified with reference to yeast Saccharomyces cerevisiae, which belongs to the natural microflora of date palm sap, showed a molecular weight in excess of $45 \mathrm{kDa}$. In fact, as reported by Ben Thabet et al. (2010), all the glycolytic enzymes which form part of the fermentation processes that occur in Saccharomyces cerevisiae to produce alcohol were identified by MALDI-TOF analyses and showed a molecular weight varying from 44.7 to $62.1 \mathrm{kDa}$. In addition, proteins that this yeast involves against stress such as ATPase of Hsp90 chaperone complex, present a molecular weight nearly $77.6 \mathrm{kDa}$. The metabolism proteins produced by Saccharomyces cerevisiae, like Acetohydroxyacid reductoisomerase, were also identified with a molecular weight of about $45 \mathrm{kDa}$ (Ben Thabet et al., 2010b).

Overall, the collection time affects the quality of Deglet Nour date palm sap (Phoenix dactylifera L.). In fact, after seven days after the beginning of the sap collection, a decrease in Brix degree, dry matter, and polyphenols contents and an increase in ash and sugar contents were observed in both male and female saps. These results might contribute to the current understanding of the effect of the collection time on Deglet Nour sap quality. This variability makes the direct industrialization of date palm sap as an UHT natural drink difficult. Accordingly, further studies, some of which are currently underway in our laboratories, are needed to produce standardized date palm sap products which will be directly used in food application or diluted to produce date palm sap. In fact, the vacuum concentration of the Deglet Nour sap will be an interesting method to produce date palm syrups (DPS) which can be used in several food formulations such as: standardized UHT drink, pastry, confectionery, milk products etc. DPS can also be subsequently commercialised like maple syrup which is produced by thermal evaporation of the colorless watery sap collected from maple (Acer) species and presents great economic importance to the north-eastern region of North America (Li and Seeram, 2011).

\section{Acknowledgements}

The authors would like to thank the staff of the "Unité de Technologie des Industries Agro-Alimentaires", Gembloux, Belgium for their valuable collaboration and help during this study. They would also like to express their sincere gratitude to Mr. Anouar Smaoui from the Faculty of Science of Sfax, Tunisia for his constructive proofreading and language polishing services.

\section{References}

Ahmad, I.S.A.; Al-Gharibi, K.N.; Daar, A.S.; Kabir, S. 1995. The composition and properties of date proteins. Food Chemistry 53: 441-446.

Atputharajah, J.D.; Widanapathirana, S.; Samarajeewa, U. 1986. Microbiology and biochemistry of natural fermentation of coconut palm sap. Food Microbiology 3: 273-280.

Barreveld, W.H. 1993. Date palms products. FAO, Rome, Italy.

Bchir, B.; Besbes, S.; Karoui, R.; Paquot, M.; Attia, H.; Blecker, C. 2010. Osmotic dehydration kinetics of pomegranate seeds using date juice as an immersion solution base. Food and Bioprocess Technology 5: 999-1009.

Ben Thabet, I.; Besbes, S.; Attia, H.; Deroanne, C.; Francis, F.; Drira, N.E.; Blecker, C. 2009. Physicochemical characteristics of date sap "lagmi" from Deglet Nour palm (Phoenix Dactylifera L.). International Journal of Food Properties 12: 659-670.

Ben Thabet, I.; Besbes, S.; Masmoudi, M.; Attia, H.; Deroanne, C.; Blecker, C. 2010a. Compositional, physical, antioxidant and sensory characteristics of novel syrup from date palm (Phoenix dactylifera L.). Food Science and Technology International 15: 583-590.

Ben Thabet, I.; Francis, F.; De Pauw, E.; Besbes, S.; Attia, H.; Deroanne, C.; Blecker, C. 2010b. Characterisation of proteins from date palm sap (Phoenix dactylifera L.) by a proteomic approach. Food Chemistry 123: 765-770.

Besbes, S.; Drira, L.; Blecker, C.; Deroanne, C.; Attia, H. 2009. Adding value to hard date (Phoenix dactylifera L.): compositional, functional and sensory characteristics of date jam. Food Chemistry 112: 406-411. 
Bouaziz, M.A.; Besbes, S.; Blecker, C.; Wathelet, B.; Deroanne, C.; Attia, H. 2008. Protein and amino acid profiles of Tunisian Deglet Nour and Allig date palm fruit seeds. Fruits 63: 37-42.

Dalibard, C. 1999. Overall view on the tradition of tapping palm trees and prospects for animal production. Livestock Research for Rural Development. 11: 1. Available at: http://www.lrrd. org/lrrd11/1/dali111.htm [Accessed Sept. 16, 2012]

Dawsan, R.M.C.; Elliott, D.C.; Jones, K.M. 1969. Data for Biochemical Research. 2ed. Oxford University Press, London, UK.

European Union. 1998. Determination of amino acid in feed by HPLC: development of an optimal hydrolysis and extraction procedure by the EU Commission DGXII in three international collaborative studies. Official Journal of the European Communities 257: 14-28

Fischer, W.N.; André, B.; Rentsch, D.; Krolkiewicz, S.; Tegeder, M.; Breitkreuz, K.; Frommer, W.B. 1998. Amino acid transport in plants. Trends in Plant Science 3: 188-195.

Food and Agriculture Organization [FAO]. 2008. Agro-statistics database. Available at: http: //faostat3.fao.org/ [Accessed Sept. 16, 2013]

Golenberg, E.M.; West, N.W. 2013. Hormonal interactions and gene regulation canlink monoecy and environmental plasticity to the evolution of dioecy in plants. American Journal of Botany 100: 1022-1037.

Gutfinger, T. 1981. Polyphenols in olive oils. Journal of the American Oil Chemists' Society 58: 966-968.

Haller, J.F.; Krawczyk, S.A.; Gostilovitch, L.; Corkey, B.E.; Zoeller, R.A. 2011. Glucose-6-phosphate isomerase deficiency results in mTOR activation, failed translocation of lipin $1 \alpha$ to the nucleus and hypersensitivity to glucose: implications for the inherited glycolytic disease. Biochimica et Biophysica Acta 1812: 13931402 .

Joy, K.W. 1988. Ammonia, glutamine, and asparagine: a carbonnitrogen interface. Canadian Journal of Botany 66: 2103-2109.

Khieu, B.; Preston, T.R. 1995. Conserving biodiversity and the environment and improving the wellbeing of poor farmers in Cambodia by promoting pig feeding systems using the juice of the sugar palm tree (Borassus flabellifer). Livestock Research for Rural Development 7:2. Available at: http://www.lrrd.org/ $\operatorname{lrd} 7 / 2 / 5 . h t m$ [Accessed Sept. 14, 2013]
Kilincceker, O.; Dogan, I.S.; Kucukoner, E. 2009. Effect of edible coatings on the quality of frozen fish fillets. LWT - Food Science and Technology International 42: 868-873.

Kwaasi, A.A.A.; Harfi, H.A.; Parhar, R.S.; Collison, K.S.; AlSedairy, S.T.; Al-Mohanna, F.A. 2008. Cultivar-specific IgE-epitopes in date (Phoenix dactylifera L.) fruit allergy. International Archives of Allergy and Immunology 2000: 137144.

Laemmli, V.K. 1970. Cleavage of structural proteins during the assembly of the heads of bacteriphage T4. Nature 227: 680-685.

Li, L.; Seeram, N.P. 2011. Quebecol, a novel phenolic compound isolated from Canadian maple syrup. Journal of Functional Foods 3: 125-128.

Naidu, S.J.; Misra, M.K. 1998. Production and consumption of wild date palm sap and country liquor in two tribal village ecosystems of eastern ghats of Orissa, India. Bioresource Technology 63: 267-273.

Obahiagbon, F.I.; Osagie, A.U. 2007. Sugar and macrominerals composition of sap produced by Raphia hookeri palms. African Journal of Biotechnology 6: 744-750.

Rao, P.V.K.J.; Das, M.; Das, S.K. 2009. Changes in physical and thermo-physical properties of sugarcane, palmyra-palm and date-palm juices at different concentration of sugar. Journal of Food Engineering 90: 559-566.

Regnault-Roger, C.; Hadidane, R.; Biard, J.F.; Boukef, K. 1987. High performance liquid and thin-layer chromatographic determination of phenolic acids in palm (Phoenix dactilyfera) products. Food Chemistry 25: 61-71.

Salaün, M.; Charpentier, S. 2001. Rapid analysis of organic and amino acids by capillary electrophoresis: application to glutamine and arginine contents in an ornamental shrub. Journal of Plant Physiology 158: 1381-1386.

Umerie, S.C. 2000. Caramel production from saps of African oil palm (Elaeis guineensis) and wine palm (Raphia hookeri) trees. Bioresource Technology 75: 167-169.

Yang, H.Q.; Gao, H.J. 2007. Physiological function of arginine and its metabolites in plants. Journal of Plant Physiology 33: 1-8. 